\title{
Schedule IV Substance
}

National Cancer Institute

\section{Source}

National Cancer Institute. Schedule IV Substance. NCI Thesaurus. Code C48677.

A category of medically useful drugs that have less potential for abuse or addiction than those of Schedules I, II, and III. 